\title{
Theses on Translation: An Organon for the Current Moment
}

\author{
Lawrence Venuti \\ Temple University. College of Liberal Arts \\ 1037 Anderson Hall \\ 1114 Polett Walk \\ Philadelphia PA 19122 \\ lvenuti@temple.edu
}

\begin{abstract}
The theses offer a general theory of translation that encompasses the relation between theory and practice and the different models of translation that generate theoretical concepts like equivalence and ethics. The instrumental model that understands translation as a reproduction or transfer of a source-text invariant is critiqued, whereas a hermeneutic model that understands translation as an interpretation that varies the source text is advanced. Verbal choices are treated as interpretive moves that vary a range of textual features according to factors that are drawn decisively from the receiving culture where they are arranged in hierarchies of value. The interpretive act performed by translation is informed by global cultural hierarchies in which value is distributed unevenly across major and minor languages, redefining the ethical and political stakes of a translation project.
\end{abstract}

Keywords: translation theory and practice; instrumentalism; hermeneutic model; interpretant; major language; minor language

Resum. Tesis sobre la traducció: un òrganon per al moment actual

Les tesis ofereixen una teoria general de la traducció que abasta la relació entre teoria i pràctica i els models de traducció, que generen conceptes teòrics com equivalència i ètica. L'article critica el model instrumental, que entén la traducció com una reproducció o transferència d'un text de partida invariable, mentre que abona l'hermenèutic, que l'entén com una interpretació que altera el text de partida. Les tries lèxiques es consideren maniobres interpretatives que fan variar una sèrie de característiques textuals segons factors que s'extreuen de la cultura receptora, en què es disposen a partir del valor jeràrquic que hi tenen. En l'acte interpretatiu de traduir hi influeixen jerarquies culturals universals, en les quals el valor es distribueix de manera desigual en les llengües grans i les petites, la qual cosa redefineix els interessos ètics i polítics d'un projecte de traducció.

Paraules clau: teoria i pràctica de la traducció; instrumentalisme; model hermenèutic; interpretant; llengua gran; llengua petita 
No practice can be performed without the assumption of theoretical concepts that both enable and constrain it. No theory can be formulated without addressing the materiality of a practice, its particular forms and procedures, which allow concepts to be made precise in thought and effective in application. ${ }^{1}$ Translation theory constitutes conceptual parameters within which practical problems are articulated and solutions discovered. But the parameters give rise only to those problems and solutions that are specifically determined by the concepts delimiting the parameters. Other problems, those that are not so determined, are excluded.

Translation theory can lead to the development of innovative translation practices while translation practices can lead to the formulation of innovative theoretical concepts. Theory without practical application devolves into theoreticism, a fetishizing of speculation that reduces translation to abstraction. Practice without theoretical reflection devolves into practicism, a fetishizing of problem-solving that reduces translation to individual verbal choices. Both extremes wind up transcending or repressing the cultural situation and historical moment that determine the nature and significance of a translated text. This transcendence promotes a presentism that sustains the status quo in translation as well as in the receiving culture at large by failing to establish a historical basis to critique them. The recourse to history can develop a critical opposition to the present that is not reducible to the ideological contradictions that divide the current conjuncture but rather seeks to imagine what might be in the future. ${ }^{2}$

Any interpretation implicitly judges a text to be worthy of interpretation, erasing the distinction between fact and value, insuring that analysis is simultaneously evaluation - even if the evaluation should prove to be negative. ${ }^{3}$ No text is directly accessible without the mediation of interpretation, whether performed by the reader on first encountering a text or preceding that reading experience and shaping or infiltrating it. Any text, furthermore, varies in form, meaning, and effect according to the different contexts in which it is situated, and so any text can sup-

1. Cf. Jacques Derrida's seminar, Theory and Practice, trans. David Wills, ed. Geoffrey Bennington and Peggy Kamuf (Chicago: University of Chicago Press, 2019), p. 86: "You can be sure that each time you try to cross over the edge of [déborder] the opposition theory/practice you'll be doing it with a gesture that will sometimes be analogous to a practice, sometimes to a theory, sometimes to both at once."

2. A reworking of Fredric Jameson's Marxist concept of historicism, in which "it is not we who sit in judgment of the past, but rather the past, the radical difference of other modes of production (and even of the immediate past of our own mode of production), which judges us, imposing the painful knowledge of what we are not, what we are no longer, what we are not yet." See Jameson, "Marxism and Historicism", New Literary History, 11/1 (1979): 41-73 (70).

3. Barbara Herrnstein Smith, Contingencies of Value: Alternative Perspectives for Critical Theory (Cambridge, MA: Harvard University Press, 1988), pp. 10-11. 
port multiple and conflicting interpretations, whether within the same historical period or spanning different periods. ${ }^{4}$

Thus, any source text comes to the translation process always already mediated by interpretive practices that position it in a network of signification. Some of these practices originate in the source culture, while others are located in the receiving culture. As soon as the translator begins to read the source text, it is mediated yet again, that is to say interpreted, and the translator's interpretation looks in two directions at once, answering not only to the source text and culture but also to the translating language and culture. The interpretation inscribed by a translation, however, is ultimately weighted toward the receiving situation. Translation is fundamentally assimilationist.

To analyze-evaluate a translation simply by comparing it to the source text is an act of self-delusion that is simultaneously self-congratulatory. The comparison is always mediated by interpretants, ${ }^{5}$ factors that perform a forceful interpretive act, but that generally go unrecognized by the analyst-evaluator. Hence the self-delusion. The interpretants start with a concept of equivalence, a relation of correspondence that supposedly the translation can and ought to establish with the source text. This concept usually stipulates a segment of that text as the unit of translation, which can range from the individual word or sentence to the paragraph or chapter, even to the entire text. The source-text unit is then fixed in form, meaning or effect to create the basis for gauging whether a comparable unit of the translation is equivalent. Finally, a code or theme is applied to determine that it is shared by the respective units, but that code amounts to the analyst-evaluator's interpretation of the source text. The interpretants that enable the comparison eliminate interpretive possibilities that depend on a different concept of equivalence, a different unit of translation, and a different code. Too often the analystevaluator's interpretation is at once suppressed and privileged beneath the blind assumption of direct access to the source text. Hence the self-congratulation.

\section{4}

Since antiquity, around the world, thinking about translation has been dominated by an instrumental model: translation is understood as the reproduction or trans-

4. These statements recapitulate Jacques Derrida's concepts of "inscription" and "iterability"; see "Violence and Metaphysics: An Essay on the Thought of Emmanuel Levinas", Writing and Difference, trans. Alan Bass (Chicago: University of Chicago Press, 1978), p. 115, and "Signature Event Context," Margins of Philosophy, trans. Alan Bass (Chicago: University of Chicago Press, 1982), p. 320.

5. The term "interpretant" is adapted from Charles S. Peirce, The Writings of Charles S. Peirce: A Chronological Edition, 1867-1871, ed. Edward C. Moore (Bloomington: Indiana University Press, 1984), 2: 53-54; Umberto Eco, A Theory of Semiotics (Bloomington: Indiana University Press, 1976), pp. 15, 69-71; and Eco, "Peirce's Notion of Interpretant," MLN 91 (1976): 1457-1472. 
fer of an invariant, contained in or caused by the source text, an invariant form, meaning, or effect. In antiquity the invariant is premised on a sacred truth or a consecration of the source language and culture; subsequently it comes to be secularized as a metaphysical essence.

Yet the invariant does not exist. If any text can support potentially infinite interpretations, then any text can be translated in potentially infinite ways. A hermeneutic model of translation, therefore, emerging first in the early nineteenth century and undergoing various permutations since that time, stands to be comprehensive and incisive. It understands translation as an interpretive act that varies the form, meaning, and effect of the source text according to intelligibilities and interests in the receiving situation. It acknowledges the linguistic and cultural differences that translation is implemented to resolve but inevitably proliferates. It is capable not only of encompassing the manifold conditions under which a translation is produced and received, but also of drawing precise distinctions among them.

Translation is imitative yet transformative. It can and routinely does establish a semantic correspondence and a stylistic approximation to the source text. But these relations can never give back that text intact. Any text is a complex cultural artifact, supporting meanings, values, and functions that are indivisible from its originary language and culture. Translation interprets a source-text process of signification and reception by creating another such process, supporting meanings, values, and functions that are indivisible from the translating language and culture. Change is unavoidable.

Thus incommensurability occasions and remains largely unaffected by translation. This fact does not, however, support claims of untranslatability. ${ }^{6}$ Such claims necessarily assume a concept of what translation is, how it should be performed, what it should yield. That concept is an instrumental model of translation, positing an invariant that should but cannot be reproduced. If any text can be interpreted, however, then any text can be translated.

5

The translator works by shifting between source-text units, setting out from the word but taking into account larger units and moving back and forth among them. Not only during this zigzagging process but also before and after it, starting with the very choice of a text for translation, the translator inscribes an interpretation by applying an intricate set of interpretants, formal as well as thematic. Formal interpretants are structural. They include: the editing that ranges from selecting a published version of the source text to sorting through source-text variants to

6. For recent examples, see Barbara Cassin, ed., Vocabulaire européen des philosophies: Dictionnaire des intraduisables (Paris: Seuil, 2004); Cassin, ed., Dictionary of Untranslatables: A Philosophical Lexicon, trans. Steven Rendall, Christian Hubert, Jeffrey Mehlman, Nathaneal Stein, and Michael Syrotinski, trans. ed. Emily Apter, Jacques Lezra, and Michael Wood (Princeton, NJ: Princeton University Press, 2014); and Apter, Against World Literature: On the Politics of Untranslatability (London: Verso, 2013). 
devising paratexts for the translation; a concept of equivalence that may be revised as the translator articulates different interpretive problems in the course of a project; and a style linked to a genre or discourse. Thematic interpretants are codes. They include: an interpretation of the source text that is formulated in commentary independently of the translation; an ideology defined as an ensemble of values, beliefs, and representations that are affiliated with the interests of a specific social group; and the function that the translation is intended to serve in the world. Formal and thematic interpretants can be reciprocally determining: a stylistic feature such as a terminology can support an independent interpretation, an ideology, or a function, and vice versa.

Interpretants are applied in translating any genre or text type in any field or discipline--humanistic, pragmatic, or technical. All translation, in every time and in every place, can be understood as an interpretive act.

\section{6}

Interpretants are derived from preexisting materials in both the source and the translating cultures. But they decisively assimilate the source text to what is intelligible and interesting to receptors - or else the resulting translation fails to be viable.

The preexisting materials consist of cultural forms and practices: patterns of usage in the translating language, past and present, standard and non-standard; traditions and conventions of producing original compositions, including styles, genres, and discourses; traditions and conventions of translation commentary and practice, including theoretical concepts and practical strategies; patterns of reception, historical as well as recent, including previous translations from the work of the source-text author as well as other source-language authors; and values, beliefs, and representations that have acquired ideological force. Interpretants are selective in their derivation from such materials, imitative yet transformative of them, even deliberately revisionary.

Translation is self-reflexive, but the translator does not exercise complete conscious control over it. ${ }^{7}$ Deriving interpretants and applying them while translating are intended actions. But translators accumulate rules and resources, strategies and solutions, some of which may originate with them while others do not. And this repertoire, both individual and transindividual, tends to recede into a preconscious state, capable of formulation and thereby returning to consciousness but deployed intuitively, often spontaneously, without critical reflection. The translator, moreover, is incapable of acknowledging every condition that determines the production of a translation. Nor can the translator anticipate its every consequence, particularly since a complex network of agents, practices, and media facilitates the circulation and reception of any translation. Unacknowledged conditions and unanticipated consequences constitute the translator's

7. An account of the translator's agency that draws on Anthony Giddens, Central Problems in Social Theory: Action, Structure, and Contradiction in Social Analysis (Berkeley: University of California Press, 1979), chap. 2. 
unconscious, which is at once psychological and political, a reservoir of personal overdetermined by collective desires. ${ }^{8}$

Translators can and do make errors which, even if their work is carefully vetted, go uncorrected. Beginning translators may misconstrue the syntactical and lexical features of the source text because of sheer inexperience or a failure to consult pertinent reference works. Experienced translators may avoid linguistic error while erring in the etymological sense of straying or deliberately deviating from the source text, rewriting it in an effort to inscribe a specific interpretation. Yet the fact is that a translator at any level of competence, even the most accomplished, can make a linguistic error without awareness or detection. Here the error may be unconsciously motivated: a source-text unit can trigger the translator's desire or anxiety which, however, is immediately repressed, leaving only the slip as the sign of its existence. This sort of error may well be overdetermined by the prestige of the source language, of the source text, or of its author in relation to the cultural situation and historical moment where the translation is produced. As a result, the slip amounts to a challenge or interrogation by the translator, whether an emulative rivalry that constructs an authorial identity, always gendered, or an ideological conflict that expresses utopian aspirations for social life. ${ }^{9}$ What remains most remarkable about translation errors is their capacity to make sense to readers and therefore to escape notice.

Interpretants, like the cultural materials from which they derive, are positioned in hierarchies of prestige or authority housed in social institutions. These hierarchies define the current conjuncture in the receiving situation while institutions regulate how and to what extent they change. ${ }^{10}$ Hierarchies of forms and practices vary not only across historical periods but also in the same period, across and within different constituencies.

Interpretants occupying a dominant position are invested with canonicity, possessing capital that may be cultural, symbolic, and economic. ${ }^{11}$ They enable a

8. A translation too can be thought along the lines of Fredric Jameson, The Political Unconscious: Narrative as a Socially Symbolic Act (Ithaca, NY: Cornell University Press, 1980).

9. This point invokes Eve Kosofsky Sedgwick, Between Men: English Literature and Male Homosocial Desire (New York: Columbia University Press, 1985), pp. 1-5, 21-27, and Jameson, The Political Unconscious, pp. 281-299.

10. Cf. Jean-Jacques Lecercle's concept of "linguistic conjuncture" in The Violence of Language (London: Routledge, 1990), pp. 201-208. See also Frank Kermode, "Institutional Control of Interpretation", Salmagundi 43 (Winter 1979): 72-86.

11. See Pierre Bourdieu, "The Forms of Capital," trans. Richard Nice, in John G. Richardson, ed., Handbook of Theory and Research for the Sociology of Education (Westport, CT: Greenwood, 1986), pp. 241-258. 
translation to circulate widely by making it readily comprehensible, acculturating the source text to what is most familiar and most valued in the receiving situation. Interpretants occupying subordinate or marginal positions may be residual, continuing from previous periods, or emergent, drawing on innovative materials that have yet to achieve wide acceptance, and they may be stigmatized in varying degrees by dominant ideologies. ${ }^{12}$ Marginal interpretants limit the circulation of a translation by demanding greater cognitive processing, acculturating the source text to what is less familiar and less valued. Yet this unfamiliarity can register the foreignness of the source text, its linguistic and cultural difference, although only indirectly. Foreignness in translation is a construction, basically tendentious, a foreignism, mediated by receiving cultural materials and opposed to the dominant.

The translator's interpretation inescapably intervenes into its conjuncture by validating or challenging cultural hierarchies. Applying marginal interpretants is ethical in questioning the dominance of canonical forms and practices over foreign texts and cultures. Applying dominant interpretants can be unethical if it maintains the status quo and no difference is registered.

\section{9}

Today, throughout the world, translating languages tend to adhere to current standard dialects. This tendency is apparent in various text types, humanistic, pragmatic, and technical, regardless of the source language and text and even though pragmatic and technical texts are likely to contain nonstandard items like jargons. The current standard dialect is the most immediately accessible form of a translating language, and when applied in translations of great fluency, it contributes to the illusionism of transparency whereby the translation seems to be not a translation, but the source text. Translators are discouraged from implementing a broad variety of dialects, styles, and discourses by publishers and editors, agencies and clients, scholars and instructors, reviewers and readers - whoever may be the projected audiences for a translation. Instead dominant forms and practices are imposed to make translations easily readable and hence consumable on the book market, as uniformly commodified as possible.

Translators should not be encouraged to abandon readability, fluency, and transparency, but rather to expand the parameters within which these effects are produced. This expansion must not be arbitrary; it should scrupulously take into account the linguistic features of the source text in relation to the cultural hierarchies in the receiving situation, establishing a necessity for the translator's interpretation. Deviating from dominant materials like the standard dialect allows the translator to take responsibility for the inevitable transformation enacted by translation insofar as such deviations qualify or limit the intercultural dominance of the receiving situation. They show respect for the source text by cultivating innovation in the translating language and culture.

12. These distinctions develop Raymond Williams, "Base and Superstructure in Marxist Cultural Theory", Problems in Materialism and Culture: Selected Essays (London: Verso, 1980), pp. 31-49. 
Languages and cultures are positioned in global hierarchies of prestige and resources underpinned and overdetermined by various conditions - economic and political, legal and military. ${ }^{13}$ The hierarchies range from majority or dominance through various subordinate positions where the relatively minor or marginal are assigned. Major languages like English and French have accumulated such capital as to make their cultural forms and practices objects of imitation and translation by minor languages, which have in turn sought to be translated into the major languages to share their capital and gain recognition. ${ }^{14}$

The hierarchies create an imbalance in translation patterns. Major languages tend to be the most translated while translating less than their minor counterparts; major languages tend to translate more frequently among themselves, consolidating their prestige and resources while neglecting languages that possess different degrees of minority. The hierarchies can also motivate the model of translation that prevails in different positions. The hermeneutic assumption of variance can issue from a minoritarian desire for cultural development and recognition or from a majoritarian complacency with hegemony that is blind to its own cultural limitations. ${ }^{15}$ The instrumentalist assumption of invariance can issue from a minoritarian investment in vernacular nationalism that underwrites essentialist concepts of cultural purity and authorial originality or from a majoritarian imposition of linguistic imperialism that extends the domination of a major language and controls the interpretation inscribed by translation. ${ }^{16}$

The ethical functions of translation likewise vary according to the unequal distribution of prestige and resources. Ethical translation at once exposes and supplies a lack in receiving cultural institutions. ${ }^{17}$ The translator into a minor language overcomes its marginality by stimulating cultural development through an engagement with major cultures. The translator into a major language interrogates its dominance by admitting languages and cultures that have been excluded.

13. A concept of "world space" that is indebted to Pascale Casanova's work but seeks to restore an Althusserian notion of the relative autonomy of social practices. See Casanova, The World Republic of Letters, trans. M. B. DeBevoise (Cambridge, MA: Harvard University Press, 2004), and "Literature as a World", New Left Review 31 (Jan.-Feb. 2005): 71-90; Louis Althusser, "Contradiction and Overdetermination: Notes for an Investigation", For Marx, trans. Ben Brewster (London: Allen Lane, 1969), pp. 87-128.

14. Pascale Casanova, "Consecration and Accumulation of Literary Capital: Translation as Unequal Exchange", trans. Siobahn Brownlie, in Mona Baker, ed., Critical Readings in Translation Studies (Abingdon: Routledge, 2010), pp. 287-303.

15. The first hermeneutic move is exemplified by the work of Catalan poet and essayist J. V. Foix (1893-1987) in his multi-faceted engagement with the modernist avant-gardes (through imitations, translations, and commentary); the second move is exemplified by Imitations (1961), the collection of adaptations produced by the United States poet Robert Lowell (1917-1977).

16. The Czech-born, French-naturalized writer Milan Kundera exemplifies both instrumentalist moves, first in his quarrels with the English translators of his Czech novels, then in his decision to write in French instead of Czech and to revise the French translations of his Czech novels.

17. A translation ethics derived from Alain Badiou, Ethics: An Essay on the Understanding of Evil, trans. Peter Hallward (London: Verso, 2001), pp. 67-71. 


\section{1}

Translations have long been read instrumentally, as if they reproduced or transferred the source text without variation. This approach renders invisible the translator's labor of interpretation. The reader succumbs to the illusionistic transparency produced by fluent translating and is thereby offered a subject-position in whatever ideological determination has been inscribed through translation.

To read a translation as a translation, the reader must assume a hermeneutic model so as to locate and process signs of the translator's work. Not only should meaning be comprehended, all too likely to be reduced to the source text, but form should be critically appreciated, the features of register, style, and discourse that uniquely characterize the translating language. Since translators worldwide work under a discursive regime that mandates the use of the current standard dialect, non-standard deviations can be taken as symptomatic of the translator's intervention. Comparison to the source text is more revealing of the translator's interpretants--provided the reader remains aware that the comparison is based on another interpretation of the source text, introduced by the reader, and not on that text itself.

The translator's verbal choices should be viewed as interpretive moves that nuance source-text structures and meanings like narrative point of view and characterization, prosody and imagery, terminology and argument, theme and ideology. The significance of these moves is deepened when they are situated in broader contexts, including other translations from the source language, original compositions in the translating language, and global hierarchies of languages and cultures. A critical dialectic can be initiated between the source and translated texts, whereby each submits the other to a probing critique, exposing their advances and limitations. In constructing these various contexts of interpretation, the reader applies a set of relevant interpretants that are themselves variable insofar as they serve changing interpretive occasions.

\section{2}

Translators themselves contribute to the misunderstanding and neglect with which translation has increasingly between treated since the beginning of the twentieth century, even with the advent of the field known as translation studies. Their self-presentations consist mostly of impressionistic remarks on their work, on its literary and cultural value, on the equivalence they believe to have established with the source texts they translate. They assume an instrumentalist notion of untroubled reproduction, which devolves, in the case of literary translators, into belletrism that privileges the aesthetic autonomy they arrogate to their translations or, in the case of translators in the human sciences, into dogmatism that privileges the dominant interpretations they inscribe in source texts or, in the case of pragmatic and technical translators, into functionalism that privileges the mechanistic solutions they apply without regard for the social uses to which the translation is put. Each group adopts, in effect, an anti-intellectual attitude towards 
translation, resisting the theoretical self-consciousness that might allow them to criticize and to improve their work as well as to provide an illuminating account of it to their readers.

Translators can contend with their marginality by aspiring to be writerly intellectuals. They can acquire specialized knowledge of their fields and disciplines so as to engage with the methods, trends, and debates that constitute those practices. They can learn to situate their projects in theoretical and practical frameworks that are not only institutional but also transnational, taking into account cultural and social conditions. They can use the translating language to register indirectly, in its particular terms, the differences that comprise source languages, texts, and cultures, mobilizing them through innovations that question the hierarchies structuring the cultural and social institutions in the receiving situation. ${ }^{18}$ As agents who traffic in the foreign, they can choose to bring to bear relentlessly a sense of foreignness that is strategic in its criticism of the status quo.

\section{3}

The term "cultural translation" is sheer tautology: translation is a practice that mediates between cultures. That term, on the one hand, severs language from culture in thinking about translation and, on the other hand, represses the actual medium in which the translation occurs. Thus, not only does the term discourage thinking about interlingual translation, but it also fosters speculative commentary that ignores the material forms and practices constitutive of translation.

It is only by foregrounding this materiality that thinking about translation can advance. Hence the frequent use of metaphors for translation creates yet another detour from rigorous exploration of translation as a cultural practice. If the words used to label and describe translation since antiquity have been fundamentally metaphorical, if language itself is metaphorical in its relation to reality, constructing analogies that rest on metaphysical assumptions, ${ }^{19}$ the unchecked formulation of metaphors is likely to obfuscate translation through essentialism.

The use of translation as a metaphor must likewise be questioned. The movement between varying kinds of media, each with their own forms and practices, has invited the application of the term "translation." Theatrical performance, film adaptation, ekphrasis, textual editing, museum exhibition - these practices have all been regarded as translational. Yet the treatment usually stops short of considering the precise concept of translation at issue. More often than not that concept is instrumentalist.

The metaphor can be productive, however, if it assumes a hermeneutic model that posits an interpretive act accomplished through the material features of a particular medium. Thinking about translation might then illuminate such other fields and disciplines as computer programming languages, constitutional law,

18. Cf. Edward Said, Representations of the Intellectual (New York: Random House, 1994).

19. See Jacques Derrida, "White Mythology: Metaphor in the Text of Philosophy", Margins of Philosophy, trans. Alan Bass (Chicago: University of Chicago Press, 1982), pp. 207-271. 
and the relations between medical research, diagnosis, and treatment. Translation might serve as the master trope for derivative works, disclosing in the process the derivative nature of source materials by calling attention to conditions that are underlying but unexpressed. ${ }^{20}$

\section{4}

A model of translation is a largely unformulated episteme that is paradigmatic, on the one hand, consisting of fundamental relations among parameters and procedures of knowledge, and generative, on the other, projecting theoretical concepts and practical strategies. ${ }^{21}$ The instrumental model, in defining translation as the reproduction or transfer of invariance, makes it transcend time and place, whereas the hermeneutic model, in defining translation as variable interpretation, makes it contingent on specific cultural situations at specific historical moments. The appearance of a binary opposition, however, is misleading: these competing approaches are both interpretations of what translation is insofar as the models are heuristic constructions that enable and constrain thinking about translation.

Yet to assert that all translation can be understood as an interpretive act, and that this understanding offers the most comprehensive and incisive account of translation - are not these claims just as transcendental as instrumentalism and therefore equally metaphysical?

No. The actual contingency of the claims must be recognized: they derive from, so as to question and change, the contemporary situation of translation theory and commentary, where instrumentalism continues to enjoy such dominance as to marginalize the hermeneutic model. What understanding of translation might emerge in the future to revise or displace the idea of interpretation constitutes the unthought of these theses.

20. Cf. Philip E. Lewis's concept of "abusive" or experimentalist translation that in "forcing the linguistic and conceptual system of which it is a dependent" winds up "directing a critical thrust back toward the text that it translates and in relation to which it becomes a kind of unsettling aftermath (it is as if the translation sought to occupy the original's already unsettled home, and thereby, far from "domesticating" it, to turn it into a place still more foreign to itself)." See Lewis, "The Measure of Translation Effects", in Joseph Graham, ed., Difference in Translation (Ithaca, NY: Cornell University Press, 1985), pp. 31-62 (43).

21. The term "episteme" is adapted from Michel Foucault, The Order of Things: An Archaeology of the Human Sciences, trans. anon. (New York: Random House, 1970), pp. xi, xxii, 168, and The Archaeology of Knowledge and The Discourse on Language, trans. A. M. Sheridan Smith (New York: Random House, 1972), part IV. 
